\title{
Virtual Worlds as an Extended Classroom
}

\author{
Ana Loureiro, Ana Santos and Teresa Bettencourt \\ CIDTFF/University of Aveiro \& Polytechnic \\ Institute of Santarém, Polytechnic Institute of Viseu, \\ $\mathcal{E}$ CIDTFF/University of Aveiro \\ Portugal
}

\section{Introduction}

There is a growing trend in education and training towards the use of online and distance learning courses. This delivery format provides flexibility and accessibility; it is also viewed as a way to provide education in a more effective way to a broader community. Online courses are comfortable, they are built under the missive of "anyone, anywhere, anytime". Everyone can participate from home or workplace.

Online courses can be developed in a variety of ways, for example, using a LMS (Learning Management System), a LCM (Learning Content System), or a Web 2.0 tool (or some mixture). These options, however, show limitations in terms of communication and interaction levels that can be achieved between students. Most learning systems are asynchronous and don't allow an effective real-time interaction, collaboration and cooperation. Whilst they typically have synchronous chats and whiteboards, these capabilities are often sterile and don't stimulate the appropriate interactions that enhance learning. A rich interaction does not necessarily involve just verbal exchange since there is an huge learning value to be gained from interacting with the learning content in a more visual and practical way. For instance, imagine the learning benefits from collaborating on a 3D construction jointly and in real-time? Imagine watching the impact of soil erosion, or building and walking inside an heart model or a car engine? All this is possible in a 3D immersive virtual world. Students can engage at a distance building content in real-time, collaboratively and interactively. On the net there can be found an array of virtual worlds, however we have chosen Second Life ${ }^{\circledR}(\mathrm{SL} \circledast)$ to show how teaching and learning can be enhanced through the use of this platform. Second Life ${ }^{\circledR}$ is immersive, enabling users to interact, communicate and collaborate as if in the real world. SL® is a model of the real world, it shows an accurate physics simulation and it includes a meteorological and gravitational system; as such, anything can be modelled and simulated. Each user in the environment is represented by an avatar with all the features of a human being and avatars can manipulate the environment. Scientific experiments can be held in a very safe and controlled environment, and can be directly conducted by the scientist in charge. Scientific fields such as architecture, history, medicine, biology, sociology, programming, languages learning among many others can all be tested and researched through this virtual world. 


\section{Virtual worlds}

There is some debate related with the definition of a virtual world. One thing that can be said is that a virtual world is not itself a game (Austin \& Boulder, 2007), besides inside of the platform who wants can play games. According to Schroeder (2008) virtual worlds are persistent virtual environments in which people experience others as being there with them - and where they can interact with them. The keyword is immersion. In a virtual world people can have immersive experiences. A virtual world can also be described as multi-user, collaborative or shared virtual environment. Those environments or systems allow users to experience other participants as being present in the same space, they can interact with each other; this creates the feeling of being there together (Schroeder, 2008). This definition is focused on sensory experience. In a virtual world "Interaction with the world takes place in real time. When you do something in the world, you can expect feedback almost immediately. The world is shared. The world is (at least some degree) persistent" (Bartle, 2004), so there is an interaction between users despite not being physically in the same space (Wankel \& Kingsley, 2009), stimulating immersive learning.

American National Standards (2007) defines a virtual world as a simulated environment that appears to have the characteristics of some other environment, and in which participants perceive themselves as interactive parts.

For Bell (2008), a virtual world is a synchronous, persistent network of people, represented by avatars and facilitated by computers.

PCMag's encyclopedia defines virtual world as a "3D computer environment in which users are represented on screen as themselves or as made-up characters and interact in real time with other users. Massively multiuser online games (MMOGs) and worlds such as Second Life are examples" (PCMag, 2011).

Here is a list of some of the best known virtual worlds: ActiveWorlds, Blue Mars, IMVU, MOOVE, World of Warcraft, OpenSim and Second Life®. Most part of these platforms were created with a social and entertainment purpose. Most of users use them to meet people, chat and socialize with others remotely. But their potentialities are not limited to the social level.

Virtual worlds already have an impact in real world society, particularly at business, art and education levels. For instance, as PCMag notes, "there are countless Second Life cultures and subcultures organized around arts, sports, games and other areas. Groups can be formed that simulate mini-companies and mini-communities. Even real companies, such as Coca-Cola and Adidas, participate in Second Life as a marketing venue. Numerous universities, including Harvard, Princeton and Vassar, offer online classes. Religious organizations hold meetings and starting with the Maldives and Sweden, countries have created virtual embassies. People find partners, have virtual sex and even get married in Second Life. In other words, Second Life is the virtual real world" (PCMag, 2011).

Talking about "real" and "virtual" in this context had led to the need to clarify the meaning of "virtual", recognizing the importance and the impact that preconceptions have in any learning or teaching or training process. Usually "virtual" is easily related to something that does not exist, that does not occupy space or consumes time, like if it belonged to another dimension that a person cannot reach because it is not tangible (Bettencourt, 2010). This is a conception of "virtual" as an antagonism of "real" that can represent an obstacle to understand and preview the educational potentialities of the virtual worlds. One must be 
aware that, in virtual worlds, when the avatar - the person is, for instance, talking with another avatar - person, those persons are really talking with each other, consuming time, discussing ideas, sharing knowledge, thinking, socializing. They are using a virtual medium to do something very real. The "virtual" has a real expression. The "virtual" must be seen and understood more like an extension of real life, than something that is antagonist to the real life. Like Bettencourt (2010) we agree that this conception is the first condition to ensure all the educational potentialities of virtual worlds.

Those potentialities are also related with another concept that arises from the immersive character of virtual worlds and from the fact that virtual worlds were not created with educational reasons in mind: the natural context of the environment where learning and teaching experiences occur (Bettencourt, 2010). This concept is not only quite different from formal, or nonformal or informal learning environments but as well is independent from them. Formal and nonformal or informal learning can be characterized by who has the control of the educational objectives or competences to achieve or to develop (Cross, 2007). In a natural context, like virtual worlds, the learning process is individual and occurs because the learner wants to no matter where he/she is, the person learns by his/her own pace, not necessarily within the context of a school, or any educational entity, in an autonomous way. Skills learned or competences developed tend to be transferable giving a whole dimension of the learning process.

As well as the learning process is individual it also depends on the socialization of the person. More the socialization more the person will learn. Within the concept of natural context that we are explaining the apprenticeships are embedded in a community of sharing (Bettencourt, 2010). This idea is inspired in the communities of practice from Lave and Wenger (1991) who, already in those years, explained the importance of sharing between newcomers and old-timers. They wrote: "We place more emphasis on connecting issues of sociocultural transformation with changing relations between newcomers and old-timers in the context of a changing shared practice" (pp. 49). The "changing shared practice" assumes an enormous actuality nowadays. In the natural context that we were explaining, the learning processes are focused in communities of sharing, where avatars - persons learn one with another. These communities are nonhierarchical and any individual contribution will enrich the whole community without any kind of value judgments.

Taking into account our experience, literature review and the research that is being developed, we believe the virtual world that offers better features and more potentialities for educational use is Second Life ${ }^{\circledR}$. This platform is the best known, more populated and integrates several and important features of usability.

We define Second Life ${ }^{\circledR}$ as a free to use 3D multi-user virtual world, immersive, imagined, designed, built and created by its users (residents or avatars). It is considered a playground for our imagination, a limitless platform - design, build, code, perform and collaborate, expanding the boundaries of creativity. It is a real life simulator (Loureiro \& Bettencourt, 2010).

\section{Exploring virtual worlds - Learning and teaching strategies}

For the most part, virtual worlds were not designed for educational use. As already mentioned, the purposes are related with social and entertainment areas although many of the features available in these platforms can be explored in educational contexts. In the 
specific case of Second Life ${ }^{\circledR}$ the simulations, emulation and role-playing features have been widely explored and with good results.

The immersive nature of SL $\AA$ allows walk through contents and information - students can learn by living or experiencing. With a 3D representation of 'self' - the avatar - learning can be done in the 1st person. Features like communication, cooperation, collaboration, interaction and information sharing are in real time. Students can learn by doing and they can more easily engage with content (Loureiro, Wood \& Bettencourt, 2010). SL® is also a major social network and a wide community of practice (Wenger, 1998). SL® is not a game but it offers the attractiveness of 3D gaming and therefore the sensation of learning by playing (Loureiro, Wood \& Bettencourt, 2010). As Lim (2009) suggested there are six learning styles that can be applied within SL®:

- Learning by exploring: students can learn by visiting and explore buildings, landscapes, communities that are simulated and modelled.

- Learning by collaborating: students can work in teams, collaboratively and in real-time on common projects or on problem-solving tasks, discussions can also be made in group and collaboratively.

- Learning by being: students can immerse in role-playing and performance activities, they can also explore the self and experiment different identities through avatar customization and by creating different characters.

- Learning by building: students can with no restrictions build any kind of objects or environments and experiencing in real-time the results.

- Learning by championing: students can get involved into activities and causes related and with an impact in real-life (such as cancer campaign, earthquake victims support).

- Learning by expressing: students can show and present their in-world activities to outside world audience, by authoring blogs, machinimas, papers, posters or by participating in conferences and meetings.

By exploring those potentialities, virtual classrooms can emerge and learning can be enhanced.

One particularly interesting feature of version 2.0 of SL® viewer is the possibility of adding shared media to an object. This means anyone can add web-based media content to the surface of any object and place it in-world or attach it to an avatar. For instance, it is possible to be inside SL $®$, running, adding and modifying contents in an external web site and the audience in-world can watch in real-time. These tasks can be made collaboratively.

Another interesting feature, especially for those who use Moodle as a LMS is the possibility of connecting and integrating it into SL® - through Sloodle (Simulation Linked Object Oriented Dynamic Learning Environment). The use of LMS in e-learning has limitations as the students only have to deal with specific activities (Yasar \& Adiguzel, 2010) but Sloodle provides a variety of tools for supporting learning contexts in immersive virtual worlds, providing experiences and opportunities for students to collaborate, cooperate and interact with the objects. By connecting Moodle and SL $®$ it is possible, for instance, to have the same chat session running in real-time on both platforms - students can chose in which one to be or connect at both. Chat logs are also saved in the Moodle database. A tool, called Webintercom, "is really useful to enhance the communication between learners who are involved in the activities within both SL® and Moodle" (Yasar \& Adiguzel, 2010) and it is 
important to students as "an aide-memoir and to help them reflect later on their experiences in the virtual world" (Livingstone, Kemp \& Edgar, 2008). Another feature of Sloodle is that SL® and Moodle accounts can be linked. This feature provides a better management of students' progress, allowing teacher to track students by their avatar names (Yasar \& Adiguzel, 2010). It is possible to set quizzes - QuizChair - where students "attempt a standard Moodle multiple-choice quiz inside SL, with the answers being stored on Moodle" (Kem, Livingstone \& Bloomfield, 2009) (in Yasar \& Adiguzel, 2010). Students can create 3D objects and deliver their assignment using drop-box tool and teachers can review their work and provide feedback in Moodle (Livingstone, Kemp \& Edgar, 2008). It also has the Presenter tool with the possibility of showing slides and/or webpages, where students can share their work in virtual space or for the teacher in class. An advantage of using Presenter is that you don't need to spend money (linden dollars - SL® currency) on uploading images (Yasar \& Adiguzel, 2010). For those who like to have a more close control over participants it is also possible to set (via a Sloodle toolbar) a function to collect a list of avatars or Moodle users connected at a certain time/date.

As a simulation or modeling tool, SL® has several uses. Many examples of buildings and cities (some of them already missing in the real world) have been built and now can be visited in SL®. The Sistine Chapel has been modelled in great detail; the aim of this recreation was to explore the use of virtual reality in the context of learning about art and architecture, allowing students experience the context, scale and social aspects of the original monument (Taylor, 2007). Another example is the reconstruction of ancient Rome or the city of Lisbon pre-earthquake $1755^{1}$. The potential is not limited to art, history or anthropology. An example in the field of physical science is related with the simplicity of how we can model molecules and observe their interactions when exposed to physical variables such as temperature. Also in the field of medicine, some experiments in training students are being conducted covering biology and doctor/patient role-play. SL® is also a great tool for language learning, with the possibility of direct contact with native speakers, allowing the development of language skills at a writing and speech level. And because there are full and reliable constructions of real world scenarios, direct contact with the culture of a country or community is a reality that is easily reachable by every classroom with an Internet connection. Generally speaking we can say that the use of 3D immersive virtual worlds in education have an important part to play since they allow multiple learning styles and they can be used in any subject of the curriculum. It allows students to acquire and develop formal competences and also to develop social and collaborative skills.

In $\S 4$ we will describe some studies that are being carried out in Second Life ${ }^{\circledR}$ by the authors of the paper.

\section{Virtual worlds as an extended classroom - Benefits}

In the following sub-sections, two examples of constructivist learning will illustrate the advantages of both distance and face-to-face education working closely together. It will be shown how they can be effective as a teaching and learning strategy.

${ }^{1} \mathrm{http}: / /$ lisbon-pre-1755-earthquake.org 
Today's students have grown up surrounded by digital society, to them traditional teaching is poorly stimulating, for their are used to utilize simultaneously diverse types of media. Currently there is several gadgets that allow access to Internet and consequently access to wireless network, so more users are connected and be able to interact with others. This reality of being connect to the network called "always on", leads to the creation of communication strategies that suits both "digital natives" and "digital immigrants" (Prensky, 2001). It's a way of communicate where users spend more time browsing and posting than in e-mail - a clear shift for social websites / social networks. There is a clear change in users behaviours, and consequently in the way how students act. For nowadays' students learning does not necessary mean being sit in rows at school. Learning is at the distance of a click, for those digitally savvy. Although, to actually retain knowledge there's the need of acquire digital skills and have digital literacy, to be able to do better research, select information, reflect, collaborate, produce, share and achieve knowledge.

Learning in a digital and connected age does not depend on "individual knowledge acquisition, storage, and retrieval; rather, it relies on the connected learning that occurs through interaction with various sources of knowledge (including the Internet and learning management systems) and participation in communities of common interest, social networks and group tasks." (Siemens, 2004). Students need to acquire certain skills and competences specific of a digital and connected society in order to "effectively benefit from e-government, e-learning and e-health services, and participate actively in the knowledge society as co-creators, and not simply consumers, as highlighted by the European e-skills strategy" (McCormack, 2010, pp 27). Besides e-skills and e-literacy competences, soft skills are also a demand. Many of the mentioned skills and competences can be practiced and enhanced in social, collaborative and virtual environments. Individuals have access to communities of practice (Wenger, 1998), virtual worlds with role-play and simulations, social networks and a wide range of web 2.0 tools. The fact of having access to different online tools demands a shift in students' profile and competences.

\subsection{The use of Second Life $®$ and online tools as an extended classroom}

We set a study in Second Life ${ }^{\circledR 2}$ to gain experience of the use of virtual worlds and social web tools (namely Facebook ${ }^{3}$ and Diigo $^{4}$ ) in learning contexts, in order to bridge the gap between students and teacher contact. We seek to understand how effective a virtual world, allied with online tools, is as a proxy for face-to-face interaction.

\subsubsection{Methodology}

This specific case study emerged from the need of observe some of the variables (cf Fig. 1) already identified (Bettencourt, 2009) and that are related with:

- $\quad$ persons and their motivations - engaging and compelling factors - to register and attend virtual worlds

- $\quad$ relationships that are established between avatars and persons - in-world relationships that evolve into out-world relationships

\footnotetext{
${ }^{2} \mathrm{http}: / /$ secondlife.com/

${ }^{3} \mathrm{http}: / /$ www.facebook.com

${ }^{4}$ http://www.diigo.com
} 
- $\quad$ social integration in Second Life ${ }^{\circledR}$ and sense of community belonging - as an allusion to Wenger's (1998) concept of community of practice

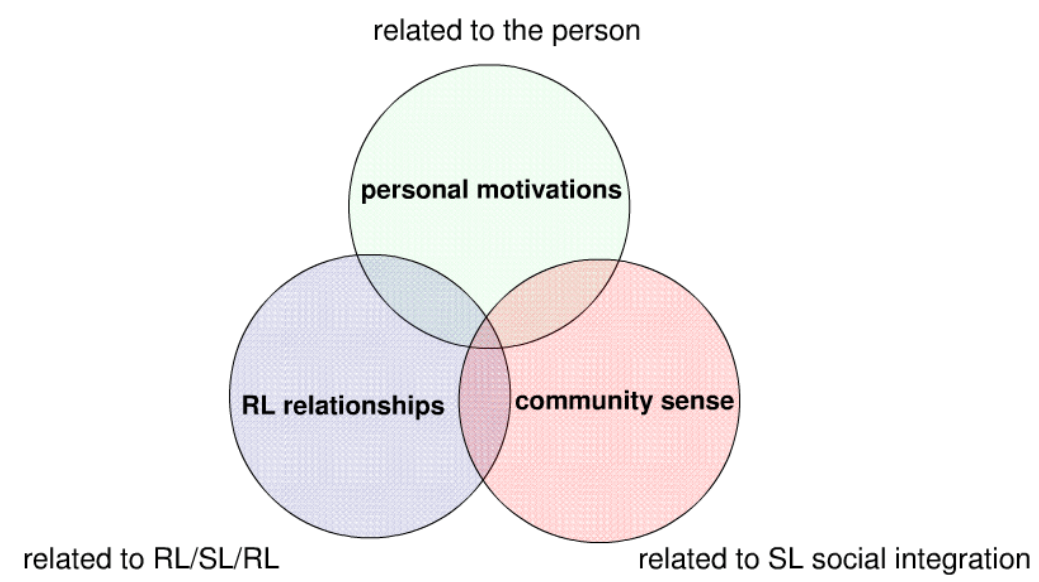

Fig. 1. Identified variables (Bettencourt, 2009)

The study components are connected with (i) construction and knowledge sharing, (ii) interpersonal relationships and (iii) 3D immersive virtual worlds combined with web 2.0 tools. We seek to understand if there are best practices orchestrating learning in collaborative, immersive virtual worlds and web 2.0 tools, and if they will enhance blended learning through knowledge sharing and socialization. The premise is that socialization is a key factor for collaborative learning. We perceive collaborative learning as a situation where two or more persons learn, or try to learn, something together (Dillenbourg, 1999).

The study goals are to:

- $\quad$ identify the variables that might influence knowledge sharing

- contribute for richer learning contexts through the use of online tools (Diigo, Facebook) and virtual worlds (Second Life ${ }^{\circledR}$ )

- $\quad$ provide tutorial support to night class through a virtual world

- encourage collaboration 'out of hours' by providing means for students and teacher to interact

- learn what advantages we can find in an online tutorial implemented using an immersive virtual world

- $\quad$ understand how and which students engage with an immersive 3D world and how effective it is as a proxy for face-to-face interaction

- understand how well online tools and virtual worlds promote knowledge sharing and enhance socialization in order to contribute for classroom cohesion

- $\quad$ provide some insights for better online teaching strategies

The participants in this study are Portuguese higher education students from a school of education. Students belong to two different groups, undergraduate regular day classes and mature night classes (ages $>23$ years old). They follow exactly the same syllabus in an identical curriculum. This is a non probabilistic sample for a qualitative study having an 
inductive and exploratory nature. The researcher, which is also the teacher, has a dual role in the study and it is a participant-observer. The data has being collected by direct observation and through electronic records; additionally questionnaires were designed to survey students for feedback.

The teacher meets each class, in a common physical space (traditional classroom), once a week. The teacher also has some hours of contact out of the classroom (support hours). These support hours suit the regular students very well but don't meet the mature students' needs since they are part time. A night class student typically has a full-time job and studies in the evenings and at weekends. The challenge for the teacher is to provide a way for students collaborate on coursework, in a tutorial context, making use of the support hours in a creative way. The main goal of the study is to encourage collaboration 'out of hours' by providing means for students and teacher to interact. The project is intended to evaluate the effectiveness of blended learning as a tool to achieve the teaching goals. Here we see blended learning as a "learning that combines online and face to face approaches" (Heinze \& Procter,

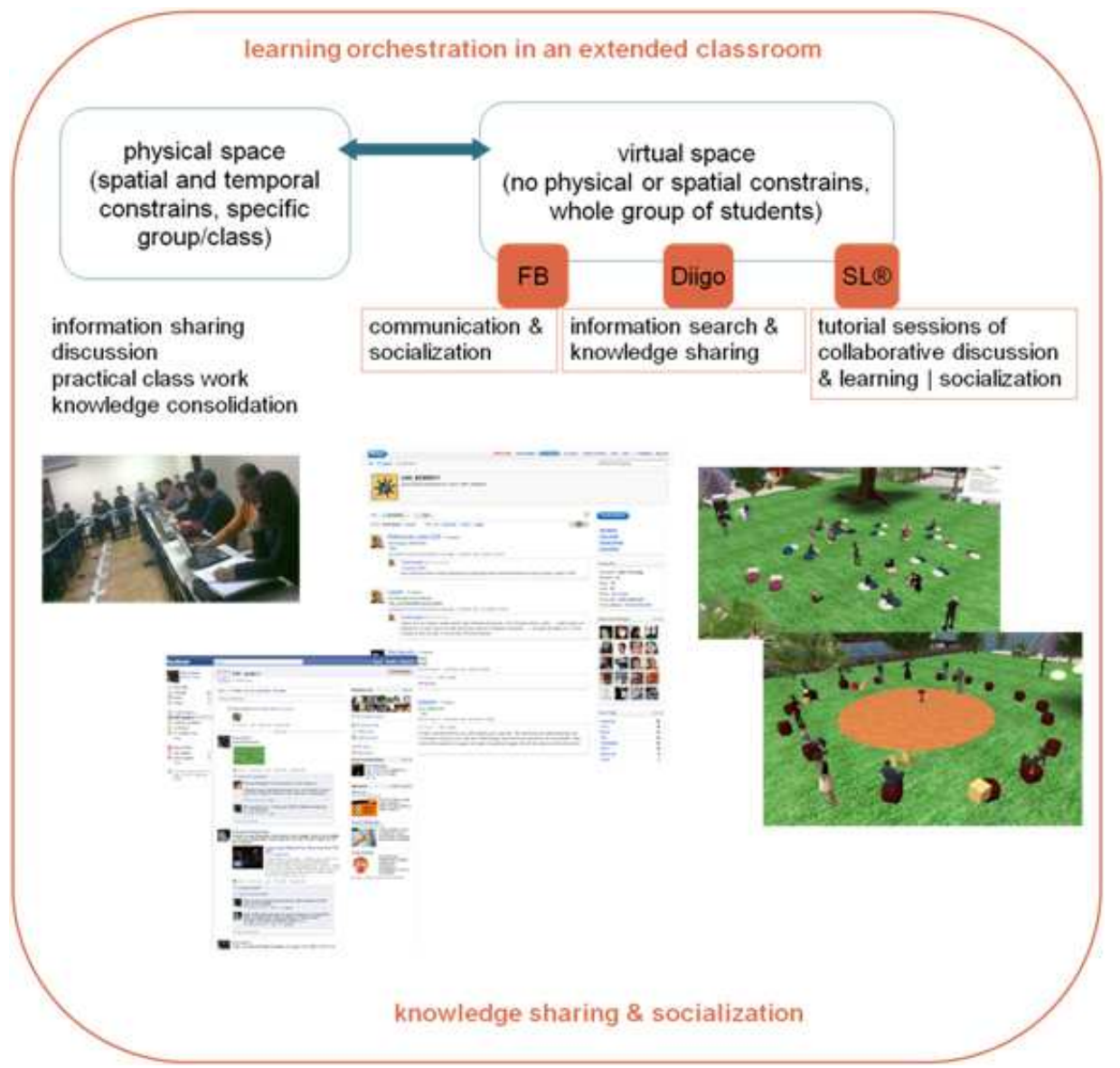

Fig. 2. Learning orchestration 
2004). In Fig. 2 we present an image showing how learning was orchestrated in the extended classroom in order to enhance knowledge sharing and socialization among students.

\subsubsection{Findings and reflections}

The study is ongoing but has already demonstrated early gains. The level and quality of participation has improved alongside increased collaboration and interaction amongst students.

First we found that the initial set up cost of starting SL® in terms of time spending was high. The students had no prior experience with the virtual world so the first tutorial session became a focus for fixing 'new user' issues. The SL® environment has a steep learning curve: how to move, how to communicate and interact, how to customize. Predominantly this was navigating the world and helping with avatar appearance. However we felt that this was time well spent as rapid integration into the virtual world is an important prerequisite to collaboration and for the survival in the virtual world. Two in-world sessions were devoted to students' acquisition of basic skills (approx. 6 hours). A number of students engaged in-world beyond tutorial hours. In future sessions it was easy to see those who had spent more time learning - avatar appearance is one indicator.

As referred a Questionnaire was used to get students feedback on their expectations and learning experiences in tutorial sessions and extended classroom. Respondents included 34 undergraduates (day and night classes) taking the same course via face-to-face and online instruction. The Questionnaire is under analyses.

With the data already collected, through observation sessions and online records, and analyzed, some preliminary findings can be outlined:

- $\quad$ tutorial sessions were considered as a success for the mature night class

- $\quad$ students didn't use the support hours available at school (physical space)

- $\quad$ night students shared more information at Diigo

- day students created a Facebook page for a more direct communication

- night students elected email as primary way for communication

- $\quad$ students posted more information than teacher, particularly night students

- the quality of shared information was high (relevant) - development of search competences

- $\quad$ posts were moderated (by teacher and students) - stimulating development of critical analysis and reflection skills

- $\quad$ students prefer in-world sessions out of official school islands - i.e informal places not perceived as an extension to the 'bricks and mortar' university

- $\quad$ night (mature) students appear more independent as learners

- night students have less time and more desire to learn in the most effective way

- night students are more motivated since they have stronger reasons to study in their spare time

- $\quad$ virtual spaces support the work patterns of mature students in particular

We can summarize saying that the contrast of behavior between day and night students is a function of maturity; level of independence as learners and intrinsic motivation. The motivation aspect needs further and deeper evaluation - where free will is involved. In that 
way we may say that an online tutorial established in a virtual world might suit better the mature students and this might be a way to help them to keep in touch with the teacher and to maintain class cohesion.

\subsection{The use of Second Life ${ }^{\circledR}$ as a virtual simulated newsroom}

In the information age, marked mostly by technological advances in communications, there's an urgent need to create courses with high-quality interactive interfaces with emphasis on student interactions with content, tutors and peers. However, technological resources are not enough to ensure those interactions in a successful way. There's also a necessity to break paradigms and change traditional teaching and learning environments. It is time to learn how to be aware of the future as learning now comes from multiple sources and acquired knowledge is never enough.

The simplicity offered by modern technological development is changing online interaction possibilities by making available to teachers and students safe interfaces, interactive and efficient communication.

Online environments put together various interfaces that allow greater interaction strategies. These tools are classified into synchronous and asynchronous. Synchronous interfaces are communication spaces that require the participation of students and teachers in scheduled events with specific times, such as chats, video conferences or conference calls. According to literature these tools have benefits such as: motivation, interaction and feedback in real-time collaborative environment.

As for asynchronous interfaces they do not depend on time or place meetings. Examples of these platforms can be pointed out discussion forums, email, blogs, wikis, etc.. Some asynchronous tools benefits are time management flexibility (allowing anytime and anywhere access) as well as time to reflect and contextualize the information and discuss ideas.

These interfaces have been shown to be extremely important for the teacher who, from that information, can better follow student learning process. Based on an innovative suggestion for collaborative learning, teachers and students can help each other in adapting to this new methodology. The intervention, the exchange of information, the collective knowledge building between students and teachers is of vital importance.

Learning through this methodology moves from an individual perspective to group learning. It puts aside the overrated assessment of independent work and rather focuses on collaboration. As so, this interface strategy for technology education is focused on solving planned activities that may require participation, cooperation, interaction and collaboration. These teaching strategies must address the student predisposition to learn and expand experience skills.

It is also important to understand that in order to develop new teaching approaches and methodologies teachers need to work on their own continuous training as well as some basic pedagogical skills. According to Market (2009) it is essential to always do a good educational process planning; to find new ways to introduce topics for discussion; to provide some minimum necessary resources for students to organize the construction of their own knowledge; to successfully deal with previously established schedule to meet the 
students; to provide a continuous learning atmosphere; to maintain constant interaction with participants throughout the course; and to gain insight on the technical and educational resources it uses.

The changes performed by digital technologies in education have brought a great deal of impact on teachers and students. Both teachers and students need to be prepared to act in this new educational format. As so in spite of using new interaction, cooperation and collaboration strategies, participation and intervention success for a course of this scope will depend on the postures adopted by those involved, and especially their willingness to take full advantage of the course.

The most appropriate and traditional learning and knowledge building environment is, of course, the school. However, historically, school has been proven to be a traditional and conservative stage so that new technologies arrival created somewhat resistance to the regular use of these digital media. Adopting new teaching and learning techniques is a challenge that inevitably will cause a change in the lives of both students and teachers. Naturally the experience says that any change requires an adjustment phase but it is always necessary in the construction of new knowledge.

The new forms of teaching and learning are opening a new paradigm in education. Considering these changes, this study main purpose is to identify in what extent a virtual simulated newsroom in Second Life ${ }^{\circledR}$ could influence the practical knowhow of the journalism students.

As students are increasingly asking for more flexible educational experiences (being able to take classes on a computer from home or work) researchers have been asked to investigate whether teaching an online class is a benefit or an obstacle to the educational experience for students. The course selected for this study provided a great opportunity to explore the value of online teaching methods.

This new teaching and learning way take full advantage of the fact that virtual worlds present a combination of a video game interface with social connections and this mean there was a great improvement of the students' practical skills as they had the chance to face real problems as if they were working on real life.

The investigation took under consideration some of the latest studies concerning e-learning and b-learning strategies and mostly learning strategies through Second Life ${ }^{\circledR}$.

As previously said the teaching/learning experience selected for this case study provided a good opportunity to evaluate some different online teaching/learning methods. As the main study focus was about practical behaviours, this popular virtual 3D platform showed to be a very handy tool to develop and at some extent evaluate a few of the Journalism course procedures. Using a new environment the study tried to evaluate the use of a 3D platform like Second Life ${ }^{\circledR}$ - for teaching and learning on higher education as well as evaluate the use of a $3 \mathrm{D}$ virtual simulation on a journalism course.

A group of the 3rd year undergraduate students participated on online classes and traditional classes in a b-learning environment. All the students involved took pre and post surveys and underwent direct observation. 
The results showed that, despite many technological handicaps, students had a better performance concerning best newsroom practices, the results also indicated that online students learned just as much as in a face to face situation and also that students enjoyed the teaching and learning experience better than the traditional way.

\subsubsection{Methodology}

In similar studies the main variable that could influence more the results relates to the sampling. For this investigation we have to add the technological skills of each individual as well as Internet access off campus for each student involved.

Having this pointed out as the first major study concern we have to access the following research questions:

RQ1: Is there a significant enhancement of journalism students' practical skills using a virtual simulation of a real newsroom?

RQ2: In what extent these virtual environments provide better basic journalism proficiency like news gathering, writing and reporting skills?

RQ3: What are the students' expectations prior and after using a new online teaching and learning methodology?

The main focus of the procedure was to virtually create a newsroom where students and teacher could gather together and decide the agenda.

The group met periodically foreseeing the problems and discussed collaboratively ways to solve those issues as so all together prepared news gathering strategies on a collectively manner.

Those meetings provided that the teacher could closely accompanying the students work progress, since getting in touch with the sources, getting interviews, news gathering, organizing information, and reporting.

In-world meetings aimed as well to support students and in real classes the group usually discussed problems they had faced and new strategies for success stories.

As a motivation goal all the students were told that they had to publish their stories on a real e-zine.

The teacher was seen as an editor-in-chief and communication in world was basically made by voice.

In short:

- Online classes were mostly concerned with reporting teams for the real e-zine

- In world meetings were also focused on the best approach choice for the articles

- All the news gathering, source interviews and report were prepared collaboratively

- Course key words: skills, work, preparation, support, feedback

Before online sessions started all students got used to Second Life ${ }^{\circledR}$ platform as - except for one - all of them had no experience with this virtual $3 \mathrm{~d}$ platform. 
Online teaching methods were developed over four in-world 60 minute sessions and these sessions had each been themed to focus on specific aspects of the journalism curriculum content.

Prior to each online session there was 30 minutes real life class mainly for technological preparation and to discuss solutions for the issues students had been facing.

Newsroom meetings took 60 minutes but students had to return back in world whenever they needed in order to get the interviews and the news gathering done as they were depending on sources agendas.

After each four in-world 60 minute sessions there was a 90 minute session of real life class.

These real life sessions were used to support the news gathering and to improve writing and reporting skills. So all the writing work was made during these face-to-face sessions and after being reviewed by the editor/teacher the articles were published on a real life e-zine.

For this investigation there was a class once a week for 180 minutes. The same instructor taught all the sessions during October 2009.

\subsubsection{Survey}

Pre/post test survey design was used to get students feedback for expectations and attitudes toward learning experiences in traditional face-to-face and online journalism courses

Respondents included 53 undergraduates taking the journalism course via face-to-face and online instruction.

The survey was used as a guide and it was taken by the students prior and after the online teaching period.

The test conducted answers on four sections:

- Demographics: questions querying students about gender and age.

- Computer literacy: to assess technology skills and confidence using those skills. At the same time students were invited to rate their internet access off campus.

- Attitudes: students had to rate their expectations and feelings towards the course.

- $\quad$ Perceived knowledge: students were asked to rate the course content as well as teaching procedures.

\subsubsection{Findings and reflections}

Under direct observation results suggested that students' experience in a journalism online course showed favourably when combined with traditional face-to-face instruction.

Results also showed that 3D multi-user environments can provide a highly immersive and very rich socially interactive way of enhancing students' skills.

Results also showed a great enhancement concerning foreseeing problems and communications and interaction showed a great improvement.

Students reported significantly better than they did at the beginning. However the course format appeared to have no impact on perceived knowledge gained. This means that the averages were virtually identical for these students and for previous year's students where 
only a face-to-face class was taken. Nevertheless students showed a lot more interest in the subjects matter.

Also by encouraging student group work the results showed that in combination online and face-to-face instruction can be a very useful way of improving the teaching and learning experience.

Students' expectations prior to online sessions: the survey results showed highly motivated and mainly curious students in spite of their poor Second Life ${ }^{\circledR}$ literacy.

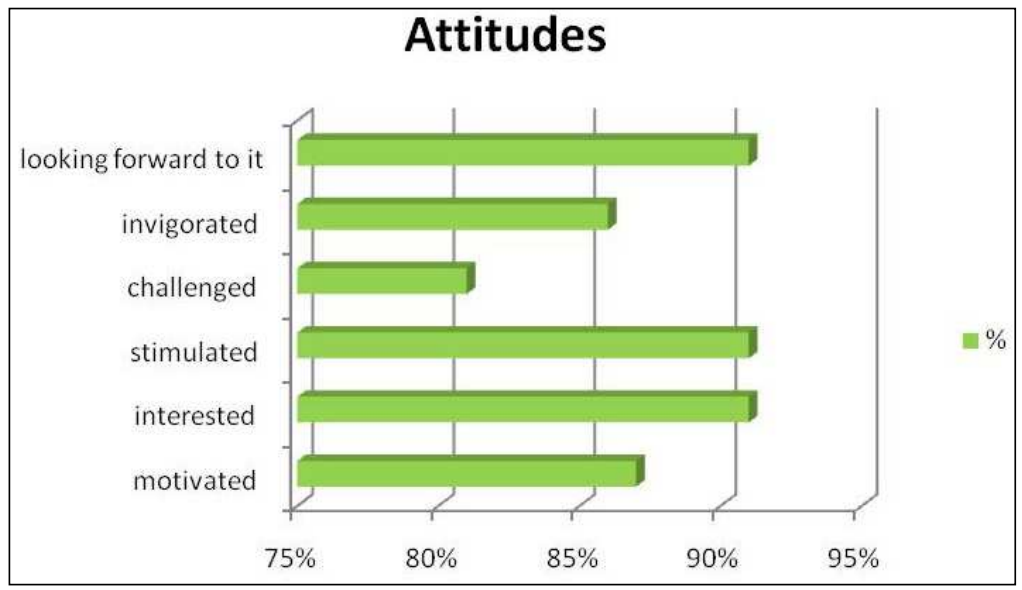

Fig. 3. Students' expectations prior to online sessions

Students' behaviours after online sessions: the survey results showed students felt inspired and find the virtual newsroom useful and very important for better journalism practices

Results showed students:

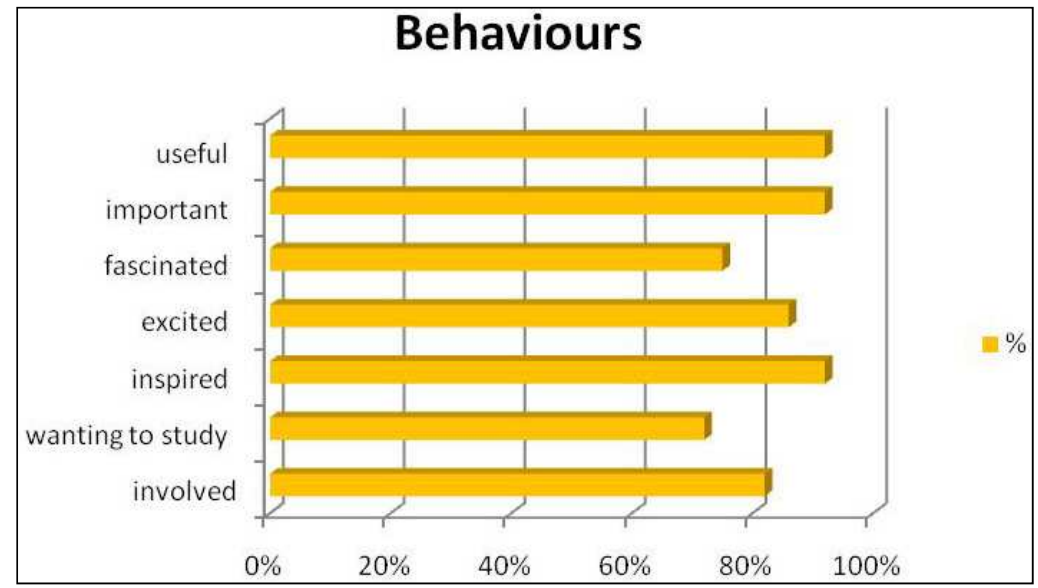

Fig. 4. Students' behaviors after online sessions 
Student strategies for the use of Second Life ${ }^{\circledR}$, such as thinking about creative solutions to problems, planning the use of time among others, point to a better integration of curricular matters seemed to be successful tasks. Also the surveyed group of students seemed to be informed about the advantages and disadvantages of specific skills that these technologies can provide in their learning outcomes.

This has already been pointed out on previous studies from Munguba, Matos and Silva (2003) which confirm that electronic media can help structuring strategies improving awareness, attention and motivation.

The strategy performed in this virtual environment was developed in order to meet the expectations of young people in the classroom and in their academic preparation.

As so students assessed that discussing the strategies according to the new methodology and study time which included topics such as optimization of the time, healthy work and educational skills in identifying and solving problems, promoting analysis and synthesis, proposed a different study, capable of promoting a better reflection and the successful execution of tasks.

These results pointed out the need for schools to reflect on their teaching practices and study strategies improvement. Taking advantage of the use of virtual environments, such as Second Life ${ }^{\circledR}$, would provide students with metacognition skills, helping them to selfregulate their learning.

These are some of the challenges faced by schools in the future moving towards the implementation of new technologies to overcome and reconcile tradition with participation curriculum contexts that will allow knowledge to make sense.

\section{Discussion and conclusions}

We see from the different learning experience we studied that the benefits of immersive approaches are significant. 3D virtual worlds can bring immersion and real-time collaboration at a distance. These environments take the distance out of distance learning. Informal and collaborative learning in natural context is the best approach as this is already practiced by students. Virtual worlds seem to make students feel more confident, more open, more participative, more creative, and more responsive. In fact, in the immersive virtual worlds, students seem to attend training sessions because they want to learn (Bettencourt \& Abade, 2008). On the other hand the establishment of virtual classrooms allows teachers to better reach and fill students' needs. The virtual classrooms can be set at a time and in a space (virtual) free of restrictions - that can be adapted, allowing a better participation from a larger number of students.

In a 3D immersive virtual world there are no physical barriers or borders. Information flows, people build and share content, relationships are set up, the net of connections extends and knowledge is built. This acquisition is made in a natural way, by participating in a community, by sharing, interact and collaborate, discussing and launching ideas, contents and information, therefore a "learning activity is (...) a conversation undertaken between the learner and the other members of the community" (Downes, 2006). It is a natural process of interaction and reflection with the guidance and correction of expertise or peers. SL $®$ for being immersive neutralizes the sensation of isolation and distance, since 
actions are taken in 1st person and can be simulated and emulated. The environment, since is built by the users, can be adapted according with needs of a specific teacher, subject or group of students.

Real-time collaboration and cooperation ally to the several connections that can be established from in-world with Learning Management Systems like Moodle or a specific webpage also gives several possibilities for learning contexts. Everything can be built, modeled, emulated and simulated - all education areas can be covered and any subject can be delivered with the help of a 3D immersive virtual world like SL $®$ and online Web 2.0 tools.

Virtual worlds and web 2.0 tools, can bring an amount of benefits for learners (Kreijns, Kirschner \& Jochems, 2003; McLoughlin \& Lee, 2007) that can be summarized in five clusters:

- Participatory learning - foster participation in creation/editing of content;

- Collaborative learning - collaborative knowledge construction (information shared by individuals can be recombined to create new forms, concepts, ideas, mash-ups and services);

- Autonomous learning - share, communicate, and discover information in communities;

- Communication and interaction capabilities - richer opportunities for networking

- Lifelong learning (join the wisdom of the crowds) - develop digital competences \& support lifelong development.

Despite the benefits, some challenges should also be considered. For learners to connect and take benefits they need to be motivated to interact. Social interaction will not automatically occur just because technology allows it. Therefore it shouldn't be taken for granted learners' capabilities and motivation to interact. The borders of the learning environment become diffused, therefore a careful planning and management is mandatory. Virtual worlds and Web 2.0 tools have their own dynamics and are transient environments - moderation becomes a requirement. Students are free to learn according with their own patterns, however a teacher or tutor should be a constant presence to guide and moderate.

Another aspect to consider is the difficulty in designing the new models of teaching and learning (Instructional Design). On the other hand higher level of anxiety are often associated with computer-mediated communication which may limit the degree of social interaction. In order to build group relationships and dynamics, students need to trust each other, feel a sense of belonging, and feel close to each other before they engage in collaboration and sharing - sense of community belonging.

Design and implement an extended classroom through the use of online tools and virtual worlds requires preparation, time and means. We cannot take participation in computersupported collaborative learning (CSCL) environments for granted, there is the need to ignite and maintain it. Students have to be prompt and reminded about their roles, they should be able to embrace autonomy but teacher needs to provide the right incentives. Interactivity has to be improved (two way connection between distributed students) by organising social interaction, collaboration and shared activities - otherwise it is unlikely to occur or be meaningful. In an extended classroom, teacher also has to foster a sense of community and encourage development of a social presence. It is very important do not replicate traditional classrooms in online environments, it is pointless if what only changes is the place/space (there is no point having students sit in rows listening to lecturers in a virtual world for instance). Employ designs that focus on collaborative, networked 
communication and interaction which seems to be what students expect nowadays without losing the informality.

It is crucial to focus more on the actors and their needs rather than the technology (it's all about people after all).

The implementation of online courses - with spaces for communication and synchronous and asynchronous interaction - can be a solution to consider in various circumstances, associated or not with the traditional classroom teaching. The use of virtual worlds allows to expand the capacity of institutions of formal education, while creating the opportunity to serve students outside of their range. The combination and adaptation of different methodologies contribute to the renewal of teaching methods and practices, making them more suited to technological developments of our time.

Web 2.0 and 3.0 are already making changes in the way students learn. It's particularly attractive to younger students who have grown up surrounded by these technologies. To digital society learners traditional teaching is poorly stimulating, for their are used to utilize simultaneously diverse types of media. Education is therefore in need of a change, to be more personalized, reflexive, social connected, involving and permitting instant gratification to embrace both native and digital immigrants (Prensky, 2001).

\section{References}

ATIS (2007). ATIS Telecom Glossary 2007 [Online]. Available: http://www.atis.org/glossary/definition.aspx?id=248 [Accessed 18 April 2011] $\mathrm{Au}, \mathrm{W}$. J. (2008). The Making of Second Life: Notes from the New World. Collins: Harper Collins.

Austin, T. \& Boulder, C. (2007). The Horizon Report, 2007. [Online]. Available: http://www.nmc.org/pdf/2007_Horizon_Report.pdf [Accessed 10 July 2010]

Bartle, R. (2004). Designing Virtual Worlds. New Riders Publishing.

Bell, M. (2008). Definition and Taxonomy of Virtual Worlds. Journal of Virtual Worlds Research [Online]. 1(1). Available: http://jvwresearch.org/page/volume_1_issue_1 [Accessed 18 April 2011]

Bennett, K., \& McGee, P. (2005). Transformative power of the learning objects debate. Open Learning, 20(1).

Bennett, S. (2005). Using related cases to support authentic project activities. In A. Herrington \& J.

Bennett, S., Agostinho, S., \& Lockyer, L. (2005). Reusable learning designs in university education. In T. C. Montgomerie \& J. R. Parker (Eds.), Proceedings of the IASTED International Conference on Education and Technology. Anaheim, CA: ACTA Press.

Bettencourt, T. \& Abade, A. (2008). Mundos Virtuais de Aprendizagem e de Ensino - uma caracterização inicial. IE communications, Revista Iberoamericana de Informática Educativa [Online] $\mathrm{N}^{\circ} 7 / 8$. Available:

http://161.67.140.29/iecom/index.php/IECom/issue/view/41/showToc [Accessed 15 September 2010]

Bettencourt, T. (2009). Teaching \& Learning in SL: Figuring Out Some Variables. [Online]. Available: http://cleobekkers.wordpress.com/2009/01/28/teaching-learning-insl-figuring-out-some-variables/ [Accessed 15 September 2010] 
Bettencourt, T. (2010). Second Life ${ }^{\circledR}$ - Uma nova forma de expressão de arte. Keynote conference on the VI Seminário Imagens da Cultura / Cultura das Imagens. Universidade Aberta e Universidade de Múrcia (Org). Porto: Universidade Portucalense, 2 Julho, Portugal.

Chee, Y. (2001). Virtual reality in education: Rooting learning in experience. In Proceedings of the International Symposium on Virtual Education 2001, Busan, South Korea, pp. 43-54. Symposium Organizing Committee, Dongseo University [Online]. Available: http:/ / yamsanchee.home.nie.edu.sg/Publications/2001/ISVE2001Invited.pdf [Accessed 18 April 2011]

Connolly, T., MacArthur, E., Stansfield, M., \& McLellan, E. (2005). A quasi experimental study of three online learning courses in computing. Computers \& Education. Vol. 49 (2).

Cross, J. (2007). Informal Learning: Rediscovering the Natural Pathways That Inspire Innovation and Performance. John Wiley and Sons, Inc. Pfeifer.

Current user metrics for Second Life, Retrieved June 2011 from http:/ / community.secondlife.com/t5/Featured-News/Q1-2011-Linden-DollarEconomy-Metrics-Up-Users-and-Usage/ba-p/856693, Secondlife.com.

Dillenbourg, P. (1999). Collaborative-learning: Cognitive and Computational Approaches, Oxford, Elsevier.

Downes, S. (2006). Learning Networks and Connective Knowledge [Online]. Available: http:/ /it.coe.uga.edu/itforum/paper92/paper92.html [Accessed 20 March 2010]

Dudeney, G., \& Hockly, V. (2007). How to teach English with Information Technology. Pearson Education Limited.

Dudeney, G., \& Ramsay, H. (2009). Overcoming the entry barriers to Second Life in higher education. In C. Wankel \& J. Kingsley (Eds.), Higher education in virtual worlds: Teaching and learning in Second Life. Bingley: Emerald Group Publishing Limited.

Hayes, G. (2009a). ROI 101 \& Stickiness of Second Life?. Retrieved May 2011 from http://www.personalizemedia.com/roi-101-stickiness-of-second-life/

Hayes, G. (2009b). Some of my 2008 reflections on Virtual Worlds, reflected elsewhere. Retrieved May 2011 from http://www.personalizemedia.com/some-of-my-2008-reflectionson-virtual-worlds-reflected-elsewhere/

Heinze, A. \& Procter, C. (2004). Reflections on the use of Blended Learning. [Online]. Available: http://www.ece.salford.ac.uk/proceedings/papers/ah_04.rtf [Accessed 10 July 2010]

Herrington (Eds.) (2006). Authentic learning environments in higher education. Hershey, PA: Idea Group Inc.

Kreijns, K., Kirschner, P. \& Jochems, W. (2003). Identifying the pitfalls for social interaction in computer-supported collaborative learning environments: A review of the research. Computers in Human Behavior, 19(3), 335-353.

Lave, J. \& Wenger, E. (1991). Situated Learning: Legitimate Peripheral Participation. Cambridge, University Press.

Lim, K. (2009). The six learnings of Second Life. Journal of Virtual Worlds Research [Online]. 2(1). Available: https://journals.tdl.org/jvwr/article/view/424/466 [Accessed 18 April 2011]

Livingstone, D; Kemp, Jeremy \& Edgar, E. 2008. From Multi-User Virtual Environment to 3D Virtual Learning Environment, Research in Learning Technology, 16: 3, 139-150 [Online] Available: http:/ /dx.doi.org/10.1080/09687760802526707 [Accessed 5 April 2011] 
Loureiro, A. \& Bettencourt, T. (2010). Immersive environments - A Connectivist Approach. In 3rd World Summit on the Knowledge Society (WSKS 2010), September 22-24, 2010, Corfu, Greece.

Loureiro, A., Wood, D. \& Bettencourt, T. (2010). Online tutorial - meeting students's needs. In I Encontro Internacional TIC e Educação (ticEDUCA2010), November 19-20, 2010, Lisbon, Portugal.

Maki, R., Maki, W., Patterson, M., \& Whittaker, P. (2000). Evaluation of a web based introductory psychology course: I. Learning and satisfaction in online versus lecture courses. Behavior Research Methods, Instruments, and Computers. Vol. 32 (2).

Mattar, J. (2008). O uso do Second Life como ambiente virtual de aprendizagem. Retrieved on March 2011 from

http:/ / www.educacaoadistancia.blog.br/revista/ucp_joaomattar.pdf

McCormark, A. (2010). The e-Skills Manifest. Available http://files.eun.org/eskillsweek/manifesto/e-skills_manifesto.pdf [Accessed 18 April 2011]

McLoughlin, C. \& Lee, M. (2007). Social software and participatory learning: Pedagogical choices with technology affordances in the Web 2.0 era. In ICT: Providing choices for learners and learning. Proceedings ascilite Singapore 2007. Available:

http://www.ascilite.org.au/conferences/singapore07/procs/mcloughlin.pdf [Accessed 18 April 2011]

Mercado, L. (2009). Integração de mídias nos espaços de aprendizagem. Em Aberto, v. 22, n. 79, p. $17-44$.

Moita, F. (2008). Second life e estratégias de estudo: interface no aprendizado de universitários brasileiros. Retrieved on January 2011 from www.anped.org.br

PCMag (2011). Virtual world Definition from PC Magazine Encyclopedia[Online]. Available: http:/ / www.pcmag.com/encyclopedia_term/0,2542,t=virtual+world\&i=59269,00. asp [Accessed 18 April 2011]

Prensky, M. (2001). Digital Natives, Digital Immigrants. Available: http:/ / www.marcprensky.com/writing/Prensky\%20\%20Digital\%20Natives,\%20Digital\%20Immigrants\%20-\%20Part1.pdf [Accessed 18 April 2011]

Rodrigue, C. (2002). Assessment of an experiment in teaching geography online. In: http://www.csulb.edu/ rodrigue/cgs02.html.

Schroeder, R. (2008). Defining Virtual Worlds and Virtual Environments. Journal of Virtual Worlds Research [Online]. 1(1). Available:

http://jvwresearch.org/page/volume_1_issue_1 [Accessed 18 April 2011]

Second Life Education Directory, Retrieved June 2011 from http://wiki.secondlife.com/wiki/Second_Life_Education_Directory, Secondlife.com.

Shelley, D., Swartz, L., \& Cole, M. (2006). A comparative analysis of online and traditional undergraduate business law courses. In:

http:/ / www.actapress.com/PaperInfo.aspx?PaperID=28526\&reason=500.

Siemens, G. (2004). Connectivism: A Learning Theory for the Digital Age. Available http://www.elearnspace.org/Articles/connectivism.htm [Accessed 18 April 2011]

Silva, E. (2003) A leitura nos oceanos da internet. São Paulo: Cortez

Taylor, S. (2007). Sistine Chapel in Second Life. [Online]. Available: 
http:/ / www.academiccommons.org/commons/showcase/sistine-chapel-insecond-life [Accessed 20 March 2010]

Thomas, R. (2001). Interactivity and Simulations in e-Learning. Retrieved on May 2011 from http://www.jelsim.org/resources/whitepaper.pdf

Twigg, C. (2003). Improving quality and reducing costs: Designs for effective learning. Change, 35, 2229.

Valente, C., Mattar, J. (2007). Second Life e Web 2.0 na Educação: o potencial revolucionário das novas tecnologias. São Paulo: Novatec.

Wankel, C. \& Kingsley, J. (2009). Higher Education in Virtual Worlds: Teaching and Learning in Second Life. Emerald Group Publishing Limited.

Wenger, E. (1998). Communities of Practice. Learning, Meaning, and Identity. Cambridge, Cambridge University Press.

Yasar, O. \& Adiguzel, T. (2010). A working successor of learning management systems: SLOODLE. Procedia - Social and Behavioral Sciences Volume 2, Issue 2, 2010, Pages 5682-5685 Innovation and Creativity in Education .[Online]. Available: http://www.sciencedirect.com/science?_ob=ArticleURL\&_udi=B9853-5016P5K$166 \& \_u s e r=10 \&$ ccoverDate $=12 \% 2 \mathrm{~F} 31 \% 2 \mathrm{~F} 2010$ \&_rdoc $=1 \&$ fmt $=$ high\&_orig $=$ gatew ay\&_origin $=$ gateway\&_sort $=d \& \_d o c a n c h o r=\& v i e w=c \& \_a c c t=C 000050221 \& \_$versio $\mathrm{n}=1$ \&_urlVersion=0\&_userid=10\&md5=8e436213aae9fb052dba019f114bf503\&searc htype $=\mathrm{a}$ 


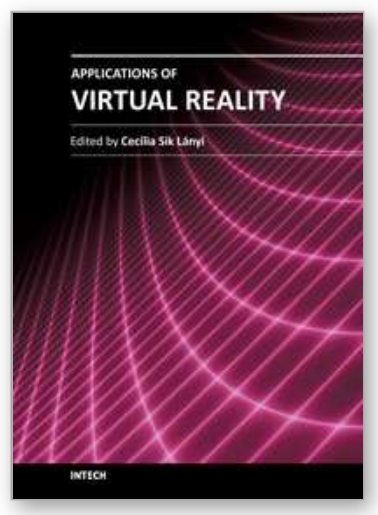

\author{
Applications of Virtual Reality \\ Edited by Dr. Cecília Sík Lányi
}

ISBN 978-953-51-0583-1

Hard cover, 210 pages

Publisher InTech

Published online 02, May, 2012

Published in print edition May, 2012

Information Technology is growing rapidly. With the birth of high-resolution graphics, high-speed computing and user interaction devices Virtual Reality has emerged as a major new technology in the mid 90es, last century. Virtual Reality technology is currently used in a broad range of applications. The best known are games, movies, simulations, therapy. From a manufacturing standpoint, there are some attractive applications including training, education, collaborative work and learning. This book provides an up-to-date discussion of the current research in Virtual Reality and its applications. It describes the current Virtual Reality state-of-theart and points out many areas where there is still work to be done. We have chosen certain areas to cover in this book, which we believe will have potential significant impact on Virtual Reality and its applications. This book provides a definitive resource for wide variety of people including academicians, designers, developers, educators, engineers, practitioners, researchers, and graduate students.

\title{
How to reference
}

In order to correctly reference this scholarly work, feel free to copy and paste the following:

Ana Loureiro, Ana Santos and Teresa Bettencourt (2012). Virtual Worlds as an Extended Classroom, Applications of Virtual Reality, Dr. Cecília Sík Lányi (Ed.), ISBN: 978-953-51-0583-1, InTech, Available from: http://www.intechopen.com/books/applications-of-virtual-reality/methodology-for-the-construction-of-a-virtualenvironment-for-the-simulation-of-critical-processes

\section{INTECH}

open science | open minds

\section{InTech Europe}

University Campus STeP Ri

Slavka Krautzeka 83/A

51000 Rijeka, Croatia

Phone: +385 (51) 770447

Fax: +385 (51) 686166

www.intechopen.com

\section{InTech China}

Unit 405, Office Block, Hotel Equatorial Shanghai

No.65, Yan An Road (West), Shanghai, 200040, China

中国上海市延安西路65号上海国际贵都大饭店办公楼 405 单元

Phone: +86-21-62489820

Fax: $+86-21-62489821$ 
(C) 2012 The Author(s). Licensee IntechOpen. This is an open access article distributed under the terms of the Creative Commons Attribution 3.0 License, which permits unrestricted use, distribution, and reproduction in any medium, provided the original work is properly cited. 